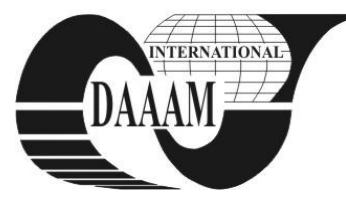

Annals of DAAAM for 2011 \& Proceedings of the 22nd International DAAAM Symposium, Volume 22, No. 1, ISSN 1726-9679 ISBN 978-3-901509-83-4, Editor B. Katalinic, Published by DAAAM International, Vienna, Austria, EU, 2011 Make Harmony between Technology and Nature, and Your Mind will Fly Free as a Bird

\title{
PRINCIPAL-AGENT RELATIONS BETWEEN LOCAL AUTHORITIES AND PUBLIC SERVICE PROVIDERS IN ROMANIA
}

\author{
GYORGY, A[ttila] \& GYORGY, A[dina] C[ristina]
}

\begin{abstract}
Local authorities represent the principal in relation with public service providers (agents) within local communities. This relation is characterized by information asymmetry which manifests itself differently depending on the agent's type of organization: either a specialized structure belonging to the authority or a specialized company held by the authority or a private company. The provider, organized in any of the presented form, aims to maximize its wealth by basing itself on the advantage of information asymmetry, underpinned on costs, level of receipt and subvention, size and structure of assets. Our study aims to evaluate the financial coordination with the budgetary funds allocated to sustain these activities in Romania. This work was supported by CNCSIS-UEFISCSU, project number PNII-IDEI 1780/2008.
\end{abstract}

Key words: principal-agent theory, local authorities, local public services providers, Romania

\section{INTRODUCTION}

This paper proposes to analyze the principal-agent relations between authorities and public service providers in the Romanian local administration. The aim of our paper is to identify the forms and disadvantages created by the information asymmetry in the Romanian local administration and the instruments which could limit the negative effects. The limitations of our research are related to the narrow geographical area subject of research and the limited number of risks and disadvantages identified.

Agency theory is based on the relations between a principal and its agent(s). Most studies are focused on the agency issues in private organizations. Lately, the information asymmetry in public sector is investigated more thoroughly in relation with public money spending and public property exploitation. Agency theory is underpinning both the relationships between the organizations and the formal contractual arrangements, typically between a government entity and a private sector service provider (Mills, 2009).

Principal-agent relations characterize the whole local public sector. The role of principals (P) and agents (A) is played simultaneously, by different actors. The mandate given by the principal to the agent may take different forms. The citizens $(\mathrm{P})$ elect the local authorities (A) to establish the conditions and the general rules of implementing the public service provision (including the size of subventions from local taxes funds). The local council $(\mathrm{P})$ mandates mayor $(\mathrm{A})$ to manage public service provision by organizing activities. The mayor $(\mathrm{P})$ mandates public service provider (A) to do the best in achieving the expected results. Public service provider $(\mathrm{P})$ uses employees (A) or outsources its activity to private companies (A).

There are several possibilities of organizing the supply of public services. Providers can be currently state owned companies, privatized companies (in past being state owned) or private companies (never having been state owned). Local authority's interraction with all of these actors is characterized by information asymmetry. In relations between local authorities and public service providers the local authority always plays the role of the principal, while public service providers represent the agents. Although the roles are fixed, the expression of the information asymmetry could take different forms.

Some scholars find agency theory exaggerating the agent's attitude which is characterized as individualistic, opportunistic, and self-serving (Davis et al., 1997). The proposed alternative is the stewardship theory which is considered by us less relevant than the agency theory, from a national perspective.

\section{PRINCIPALS AND AGENTS}

The principals are represented by the local authorities. The role of principals is to insure public services to citizens directly or throughout companies (sate owned or private). In each case, the role of principal is to finance and supervise the activity.

Principals should insure the initial capital and also finance investments, especially at the beginning of the activity. If public services are offered for free, local authorities should cover all the costs from the local budget.

Financial resources should be transferred periodically to providers from local budget in order to cover, entirely or partially, the costs. In this way, services can be offered for free or against smaller charges. The quantum of budgetary financial resources differs depending on the local council's strategy, financial power, and national legislation applicable.

Principals are focusing on controlling costs in order to enhance effectiveness of spending public money. The sensible cost items are limited. Usually, level of wages is established periodically, if possible in a transparent manner. The unnecessary expenditures are excluded, particularly when budgetary funds are granted. Agents are represented by public service providers. The whole activity of the agent is supervised by the local authority in order to assure itself on delivering the desired public services. Agents should organize their activity dependent on the principal's policy.

Relations between principal and agent are bidirectional. Both of them want to maximize wealth, but these desiderata affect the other's results. Principal will act to strengthen its welfare and will try to limit agent's activities that deems inappropriate. For analyzing the agent's activity, principal claims report and financial situations. Being an information asymmetry, the agent will decide how to react to principal's request based on its maximization benefit. In a first stage, the agent is tempted to offer incomplete data. If this is not possible, the activity in controlling assessed parameters is made in order to improve its image in relation with the principal. Acting in this way, other non-assessed activities will be neglected.

The financial approach of the principal-agent relations as well as the information asymmetry can be observed while analyzing the costs, the level of receipt, the budgetary funds and finally the size and structure of assets involved.

Costs include all the expenditure made by the provider. The utility of some items and the efficiency of using resources are difficult to be evaluated, especially by someone who is outside of the organization (such as the principal). Cost analysis should 
be made separately based on the resource quantity used, respectively the unitary price of these resources. It should be taken into account that principals virtually never enjoy representation of an agent with the same cost-to-benefit ratio for expending resources on the completion of a given productive task (Petreson, 2007).

Resource quantity used in the process of supply is standardized especially in raw material usage. These standards are based on historical records of the provider. In many situations, inefficient use of resources in the past is repeated in the present regulations encouraging waste. Unitary cost represents the cost afferent to one production unit. It should be formed on the market. Electronic public procurement procedure is compulsory only when budgetary funds represent more than half. The management board of the providersmight be interested in purchasing raw materials at a higher unitary price than the best offered if indirectly they could obtain personal advantages from their business partner, to the detriment of the provider. Receipts from beneficiaries represent the main revenue source for public service providers. Receipts are influenced by the charged quantity and the unitary price. Both parameters are differently established as compared to a competitive market.

Charged quantity for public services may differ from those offered because in some situations not all delivered services appear in the issued invoices. The quantity of the delivered public services is limited by the provider's technical possibilities and the financial resources, but it is established by local authority's public policy. Unitary price results by diminishing unitary costs with subventions. For short periods, unitary prices can be even lower if past profits can cover the gap or creation of arrears is accepted.

Level of subvention is vital in public service delivery. If activity could be done without subventions, it is recommended to be delivered by a private company. This alternative could be taken into account when provider offers public services to all potential beneficiaries from the community. Local authority's policy is not to reduce subventions, but to create conditions to cover all areas with potential beneficiaries. The unitary cost and unitary investment of extension increase as coverage approaches $100 \%$.

Provider's assets reflect the total tangible and intangible resources owned or controlled to produce value. Each type of assets can contribute differently to the provider's performance. Buildings and machines should be sized dependently to the activity. Cash should cover current payments. The exceeding amounts should be invested in short term deposits. Investments in stocks should be excluded because such investments are not proper to public service providers. Amounts to be recovered from debtors should be monitored carefully and began enforcement procedure while debts are not such high that recovery generates social problems.

Provider's liabilities are obligations arising from past transactions or events, the settlement of which may result in the transfer or use of assets, provision of services or other yielding of economic benefits in the future. Capital invested by local authority represents the fundamental liability which will remain permanently at the disposalof the provider. The main threat is represented by the debts which become arrears in time.

\section{INSTITUTIONAL DESIGN}

Depending on the institutional framework, agents can be departments of local authorities or private companies (held by the local authority or not). In the first case, the activity of the providers is not profit orientated, while in the second case companies could get returns from their activity. In both cases, budgetary funds contribute to keep a float activity. In case of private business, these funds motivate and justify further activities. Public service providers have the possibility to organize themselves in networks. It is not quite clearly assessed if this type of organization proved a higher effectiveness level in comparison with individual providers (Provan and Milward, 2001). Any solution chosen, local authority is basing on the fact that private and public interests are interdependent (Mahoney et al., 2009).

Although outsourcing solutions are multiple, in Romania public structures organized as stated owned companies subordinated to local authorities are preferred. There are cases when small local authorities chose to incorporate public services delivery in their current activity because these activities do not weight significantly in the overall activity. Private companies are chosen in few cases.

Analyzing the market, public services are offered in most cases in monopoly or oligopoly conditions. Even there are more providers in the same area, there is a trend to unify them, instead to encourage competition between them. Even more providers are grouped in a single legal person, so there are possibilities to manage financial activity separately.

Monopoly was strengthened with decentralization because regional oligopoly markets were fragmented and become local monopoly markets. Public service consumers are pushed to consume the services offered by local provider, even if in neighborhood other providers offer qualitatively better services. We consider that decentralization is beneficial, but local authorities should offer budgetary funds to those providers who offer services to their citizens, regardless of the providers' way of functioning. Local provider's unconditional support could affect the quality of the delivered services because the provider is not motivated to improve services.

\section{CONCLUSION}

In Romania, public service provision can be accomplished throughout several types of organization which actively benefit from their situation in relation with the local authorities.

Market organization in monopoly and oligopoly does not confer advantages to citizens, but makes more difficult the authorities' actions. Motivating providers and supplying similar public services in each community could improve this situation. It remains for the research studies to find solutions for the effective ways of reducing information asymmetry in this field in order to ameliorate citizens' condition.

\section{REFERENCES}

Davis, J.H.; Schoorman, F.D. \& Donaldson, L. (1997). Toward a Stewardship Theory of Management, Academy of Management Review, Vol. 22, No. 1, pp. 20-47

Gilson, R.J. \& Whitehead, C.K. (2008). Deconstructing Equity: Public Ownership, Agency Costs, and Complete Capital Markets, Columbia Law Review, Vol. 108, No. 1, pp. 231264

Mahoney, J.T.; McGahan, A.M. \& Pitelis, C.N. (2009). The Interdependence of Private and Public Interests, Organization Science, Vol. 20, No. 6, pp. 1034-1052

Mills, D. (2009). Achieving better stewardship of major infrastructure assets through configuration of governance arrangements utilising Stewardship Theory, Paper presented at IRSPM XIII Conference

Peterson, C.L. (2007). Preemption, Agency Cost Theory, and Predatory Lending by Banking Agents: Are Federal Regulators Biting Off More Than They Can Chew?, Available from: http://www.wcl.american.edu/journal/ lawrev/56/peterson.pdf?rd=1 Accessed: 2011-01-31

Provan, K.G. \& Milward, H.B. (2001). Do Networks Really Work? A Framework for Evaluating Public-Sector Organizational Networks, Public Administration Review, Vol. 61, No. 4, pp. 414-423 